\title{
Özengen Çalgı Eğitimi Alan Bireylerin Çalgı Çalmayı Öğrenmeye Yönelik Görüşleri (Çanakkale ve Balıkesir Örneği)
}

\author{
Doç. Dr. Özge GENÇEL-ATAMAN* \\ Balıkesir Üniversitesi, Necatibey Eğitim Fakültesi, Güzel Sanatlar Eğitimi Bölümü, Balıkesir / Türkiye, \\ ogencel@balikesir.edu.tr, ORCID: 0000-0002-4621-8609

\section{İbrahim GÜLER}

Balıkesir Üniversitesi, Sosyal Bilimler Enstitüsü, Müzik Eğitimi Yüksek Lisans Programı, Balıkesir / Türkiye, mox613@gmail.com, ORCID: 0000-0003-4385-202x

\section{$\ddot{\mathbf{O} z}$}

Bu çalışmada resmî ve özel yaygın eğitim kurumlarında özengen çalgı eğitimi alan bireylerin çalgı çalmayı öğrenmeye yönelik görüşlerinin belirlenmesi amaçlanmıştır. Nitel araştırma yöntemlerinden durum çalışması olarak desenlenen bu araştırmanın çalışma grubu, Çanakkale ve Balıkesir illerindeki resmî ve özel yaygın eğitim kurumlarında özengen çalgı eğitimi alan 26 katılımcıdan oluşmaktadır. Çalışmada veri toplama aracı olarak yarı yapılandırılmış görüşme tekniğinden yararlanılmış ve elde edilen verilerin analizinde içerik analizi yöntemi kullanılmıştır. Çalışmanın veri analizi merhalesinde verilerin kodlanması, temaların oluşturulması, temaların düzenlenmesi ve bulguların yorumlanması şeklindeki dört basamaklı merhale izlenmiştir. Çalışmada elde edilen veriler doğrultusunda, çalgı çalmayı öğrenmenin bireylerin kişisel yaşantı, 
sosyal çevre ve müziği meslek edinme düşüncesi üzerinde etkili olduğu sonucuna ulaşılmış ayrıca güdülenme, tutum, öz yeterlik inancı ve üstbilişsel farkındalığın çalgı çalmayı öğrenme ile yakından ilişkili olduğu belirlenmiştir. Çalışmada varılan sonuçlar doğrultusunda güdülenme, tutum, öz yeterlik ve üstbilişsel farkındalık gibi kavramların özellikle özengen çalgı eğitiminde ölçülebileceği ölçme araçlarının geliştirilmesi önerilebilir.

Anahtar Kelimeler: Müzik eğitimi; Özengen müzik eğitimi; Çalg1 eğitimi; Özengen çalgı eğitimi; Çalgı çalmayı öğrenme.

\title{
Opinions of Individuals Who Have Taken Amateur Instrument Education on Learning to Play Musical
}

\section{Instruments (Sample of Çanakkale and Balıkesir)}

\begin{abstract}
In this study, it was aimed to determine the opinions of individuals who have taken amateur instrument education in formal and private non-formal education institutions about learning to play the instrument. The study group of this research, which is designed as a case study, is comprised of 26 participants who have taken amateur instrument training in public and private non-formal education institutions in Çanakkale and Balikesir. In the study, semi-structured interview technique was used as a data collection tool and content analysis method was used to analyze the data obtained. During the data analysis phase of the study, the fourstep stage was followed as coding data, creating themes, organizing themes and interpreting the findings. During the data analysis phase of the study, the four-step stage was followed as coding data, creating themes, organizing themes and interpreting the findings. According to the data obtained from the study, it was concluded that learning to play instruments was effective on individual life, social environment and the idea of acquiring a profession, and it was determined that motivation, attitude, self-sufficiency belief and metacognitive awareness were closely related to learning to play the instrument. In line with the results obtained in the study, it can be suggested to develop measurement tools in which concepts such as motivation, attitude, self-sufficiency and metacognitive awareness can be measured especially in amateur instrument education.
\end{abstract}

Keywords: Music education; Amateur music education; Instrument education; Amateur instrument education; Learning to play instrument. 


\section{Extended Summary}

\section{Purpose}

Making music is not only an activity performed by individuals who have acquired as a profession. It is an activity that anyone who is interested in music, cares and willing to make financial and moral sacrifices in order to receive music education can perform at a certain level. At this point, amateur music education responds to the wishes and needs of individuals who want to learn music without the concern and expectation of financial gain (Bingöl, 2010). On the other hand, amateur music education can carry some individuals up to professional musicianship (İmik and Dönmez, 2017). Amateur music education, which also plays an important role in the orientation of individuals with an interest and ability to music, is also important in terms of being a bridge between general and vocational music education (Çağlar, 2017).

Regardless of the type of music education, instrument education meets the psychological needs of individuals such as expressing themselves freely and accomplishing something (Hancioğlu, 2010). Instrument learning and teaching are the most important social activities of general and amateur music education. The aim of amateur instrument training is to educate competent amateur musicians in a very informal process in contrast to professional instrument training which requires high level discipline and focuses on technique (Cope, 2002).

The lack of age restriction in amateur instrument training enables individuals of all ages to learn the instrument and the instrument learning is realized as social activity, entertainment and personal satisfaction. Therefore, amateur instrument training is shaped in line with the wishes, expectations, demands, music susceptibility, skill level and time of the individuals.

Instrument education, which is of great importance in the amateur music education, is influenced by the interests, wishes, thoughts and opinions of the individuals receiving this education and is shaped in line with all these. In this context, the aim of this study is to determine the opinions of individuals who have taken amateur instrument education in formal and private non-formal education institutions about learning to play the instrument.

\section{Method}

This study is designed as a case study which is the qualitative research methods. The study group of this research is comprised of 26 participants who 
have taken amateur instrument training in public and private non-formal education institutions in Çanakkale and Balıkesir. In this study, semi-structured interview technique was used as data collection tool. Interview questions prepared by the researchers for the purpose of the study were presented to the views of 3 instructors who are experts in the field of music education in order to ensure the content validity, and the opinions received were evaluated and the interview form was finalized. The final form consists of 15 questions, 6 of which are related to personal information and 9 of which are related to the subject. The interviews were conducted one-to-one and it was recorded as a digital audio file. In the study, the concepts of credibility, transferability, consistency and confirmability were used to determine the validity and reliability. Content analysis method was used in the analysis of the data obtained in the study. The chapters forming a meaningful whole from the texts were coded and a code list was created. Codes showing similar features in the code list were brought together and themes were reached. Descriptive tables have been created by giving examples of opinions regarding the codes collected under the themes as Participant 1 (K1), Participant 2 (K2).

\section{Results}

In line with the results of this study, it was concluded that learning to play the instrument is effective on individual life, social environment and the idea of acquiring music as a profession. On the other hand, based on the opinions of the individuals who have taken amateur instrument education, it has been determined that motivation, attitude, self-sufficiency belief and metacognitive awareness are closely related to learning to play the instrument.

\section{Discussion and Conclusion}

According to Lehr (1998), music is a tool that affects individuals 'lives and is influenced by their lives and contributes to individuals' success in academic, cultural and social fields by developing their skills (Kılıç, 2007). In this context, it has been determined that learning to play the instrument has positive effects of personal life, such as evaluating time efficiently, improving the perspective towards life, contributing to business, academic and social life, developing musical life, getting away from the intensity of life and supporting physical development. On the other hand, the time allocated to learn to play the instrument in personal life brings with it the necessity to postpone some physical needs and also to affect the academic life in terms of time. When it is thought that amateur music education is realized in line with the wishes and 
tastes of individuals, unlike professional music education, it seems normal to encounter some negative effects.

It is a known fact that learning to play instruments has a great impact on the social environment as well as personal life. According to the findings, it has been concluded that amateur instrument training creates curiosity in the social environment and can direct the surrounding individuals receive instrument training. One of the most important results of the study is the relationship between learning to play instrument and motivation. According to the opinions obtained, it was determined that the participants had positive attitudes such as being happy to play the instrument, thinking of playing the instrument as a relaxing action and believing that they can play the instrument. On the other hand, it was found that the individuals who have taken amateur instrument education had feelings and thoughts about self-sufficiency such as belief, proud, self-confidence, excitement or fear of making mistakes. In addition, it was concluded that individuals who have taken amateur instrument education have developed metacognition that it is difficult or easy to play the instrument before starting instrument training. According to another result of the study, it was determined that some participants considered amateur music education as a step to acquire a profession other than hobby and made plans for their professional life with amateur music education.

\section{Giriș}

Müzik eğitimi, temelde müziksel davranış kazandırma, müziksel davranışı değiştirme ve müziksel davranış geliştirme sürecidir. Bu süreçte, eğitim gören bireyin müziksel yaşantısı temel alınıp bu temelden yola çıkılarak belirli amaçlar doğrultusunda planl, düzenli ve yöntemli bir yol izlenerek belirli hedeflere ulaş1lır. Böylece müzik eğitimi yoluyla, bireyin özellikle müziksel çevresi arasındaki iletişim ve etkileşimin daha sağlıklı, daha düzenli, daha etkili ve daha verimli olması beklenir (Uçan, 1997). Müzik eğitimi, genel, meslekî ve özengen olarak 3 şekilde sinıflandırılmaktadır. Jentzsch, Mkrtchian ve Kansal (2014)'in da belirttiği gibi yapılan birçok araştırma, müziğin bireylerin fiziksel ve psikolojik işleyişi üzerindeki güçlü olumlu etkisini kanıtlar niteliktedir. Bu nedenle müzik, yalnızca meslek edinme eğitimi açısından değil, genel ve özengen eğitim açısından da insan yaşantısına büyük katkı sağlayan bir süreçtir.

Müzik eğitimi sınıflandırması içinde Karakoç ve Şendurur (2015)'a göre özengen müzik eğitimi, müziğin belli dalına, amatör olarak ilgi duyup 
bunu geliştirmek, müziksel davranış kazanmak ve müzikten zevk almak amac1yla herkese açı bir müzik eğitimi türüdür. Müzik yapmak sadece müziği meslek edinmiş bireylere özgü ve bu bireylerce yapılan bir etkinlik değildir. Müziğe ilgi duyan, özenen ve müzik eğitimi alabilmek için maddi ve manevi fedakârlık yapmaya gönüllü herkesin belirli bir düzeyde gerçekleştirebileceği bir etkinliktir. Bu noktada özengen müzik eğitimi, müziği maddi kazanç kaygıs1 ve beklentisi olmadan öğrenmek isteyen bireylerin istek ve gereksinimlerine cevap vermektedir (Bingöl, 2010). Diğer yandan özengen müzik eğitimi, bazı bireyleri profesyonel müzisyenliğe kadar taşıyabilmektedir (İmik ve Dönmez, 2017). Müziğe ilgisi ve yeteneği olan bireylerin meslekî alana yönelmesinde de büyük rol oynayan özengen müzik eğitimi, genel ve meslekî müzik eğitimi arasında köprü olması bakımından da büyük önem taşımaktadır (Çağlar, 2017).

Özengen müzik eğitimi, örgün ve yaygın eğitim içinde yer almaktadır. Örgün eğitim kapsamındaki ilköğretim, ortaöğretim ve yükseköğretimde; eğitsel kol çalışmaları, seçmeli dersler, ses ve çalgı toplulukları, isteğe bağlı düzenlenen bireysel ve toplu müzik kursları ile gerçekleşmektedir. Yaygın eğitimde ise özel kuruluşların düzenledikleri kurslar, özel dersler, konserler, festivaller, yarışmalar özengen eğitim için oldukça önemli bir yere sahiptir (Uçan, 2005). Özengen müzik eğitiminin örgün ve yaygın eğitim içinde yer alması müzik eğitimi almak isteyen bireylere büyük imkanlar sağlamaktadır. Güleç (2018)'e göre örgün eğitimde müzik eğitimi alamayan bireylerin yaygın eğitimin getirdiği avantajlar sayesinde eğitim alabilmeleri bireylerin müzik eğitimi alma isteklerini karşılayabilmektedir. Ülkemizde giderek önem kazanmakta olan özengen müzik eğitimi, yaygın eğitim açısından bireysel yapılabildiği gibi kurumsal olarak da halk eğitim merkezleri gibi resmî kurumlarda ve özel müzik kursları gibi özel kurumlarda yürütülmektedir. Bu kurumlarda özengen müzik eğitimi hem müziğe yeni başlayanlar hem de müzikte belli bir seviyede olup kendini daha ileri bir seviyeye taşımak isteyenler için belirli eğitim programları çerçevesinde farklı seviyelerde verilmektedir. Ayrıca bu kurumlar hem müziği amatörce düşünenlere hem de ileride profesyonel olmayı tasarlayanlara eğitim hizmeti vererek ülkemiz müzik eğitimine de önemli katkılar sağlamaktadır (Karan, 2011; Özdek, 2006; Tepeli, 2018).

Dünyada ve ülkemizde özengen müzik eğitimi oldukça önemli bir geçmişe sahiptir. Örneğin Say (1998)'a göre Avrupa'da amatör olarak kurulan oda müziği grupları ve orkestralar özengen müziğin yaygınlaşmasında önemli 
roller üstlenmiştir. Ayrıca New York'taki Julliard School of Music ve Londra'daki Royal Collage of Music gibi okullar oldukça ciddi eğitimlerin verildiği özengen müzik eğitimi kurumlarının başında gelmektedir (Çağlar, 2011). Ülkemizde de Başkent Oda Orkestrası bu amaç doğrultusunda amatör bir orkestra olarak kurulan ve varlığını profesyonel seviyede günümüzde de sürdüren en önemli örnekler arasındadır (Say, 1998).

İster meslekî ister genel ister özengen olsun çalg1 eğitimi müzik eğitimi içinde çok önemli bir yere sahiptir. Çalg1 eğitimi, insanın kendisini fark etmesi, algılayabilmesi, tanıyıp tanımlayabilmesi, var olan becerilerini aldığ 1 eğitim aracılığıyla geliştirmesi ve bu sayede kendisini gerçekleştirme imkânı vermesi bakımından müzik eğitiminin önemli bir boyutudur. (Yıldırım-Orhan ve Ercan, 2012). Müzik eğitiminin hangi türünde olursa olsun, çalg1 eğitimi bireylerin kendini özgürce ifade etmesi ve bir şeyi başarıyor olması gibi psikolojik gereksinimlerini karşılamaktadır (Hancıoğlu, 2010). Çalg1 öğrenme ve öğretme genel ve özengen müzik eğitiminin en önemli sosyal aktiviteleridir. Özengen çalg1 eğitiminde amaç, üst düzey disiplin gerektiren ve tekniğe yoğunlaşan meslekî çalgı eğitiminin aksine çok resmî olmayan bir süreçte yetkin amatör müzisyenler yetiştirmektir (Cope, 2002).

Özengen çalg1 eğitiminde yaş sınırlamasının olmaması, her yaştan bireyin çalg1 öğrenebilmesini ve çalg1 öğrenmenin sosyal etkinlik, eğlence ve kişisel tatmin olarak gerçekleşmesini sağlamaktadır. Ancak yaş ilerledikçe devinişsel davranış kazanmanın zorluğu ve özengen çalgı eğitimi alan bireylerin çalgıya ayırabildikleri zamanın meslekî çalgı eğitiminden farklılık göstermesi, özengen alan özelliklerini göz önünde bulundurmayı gerektirmektedir (Davidson ve Jordan, 2007). Bu nedenle özengen çalg1 eğitimi, eğitim alan bireylerin istek, beklenti, talep, müziğe yatkınlık, beceri düzeyi ve çalışmak için ayırdığg 1 zaman doğrultusunda şekillenmektedir. Bu durum özengen çalg1 eğitimini, uygulanan programın yoğunluğu, erişilmesi planlanan hedef ve beceri düzeyi bakımından meslekî çalg1 eğitimine göre daha esnek ve kişiye özel kılmaktadır (Bingöl, 2010).

\section{Araştırmanın Amacı}

Müzik eğitiminin tüm türlerinde olduğu gibi özengen müzik eğitimi içinde de büyük bir öneme sahip olan çalg1 eğitimi, bu eğitimi almakta olan bireylerin ilgi, istek, düşünce ve görüşlerinden etkilenmekte ve tüm bunlar doğrultusunda şekillenmektedir. Bireylerin bu eğitim sürecine ilişkin görüşve 
düşüncelerinin belirlenmesi, özengen çalg1 eğitimi ile ilgili sorunların giderilebilmesi ve bu eğitim sürecinin daha sağ lıklı bir şekilde sürdürülebilmesi aç1sından önemli görülmektedir. Bu bağlamda bu çalışmanın amacı; resmî ve özel yaygın eğitim kurumlarında özengen müzik eğitimi alan bireylerin çalgı çalmayı öğrenmeye yönelik görüşlerinin belirlenmesine yöneliktir. Çalışmanın amacı doğrultusunda:

- Özengen çalg1 eğitimi alan bireylerin çalgı çalmayı öğrenmek istemelerinin nedenleri nelerdir?

- Çalg1 çalmayı öğrenmenin özengen çalg1 eğitimi alan bireylerin hayatlarına kattığ1 etkiler nelerdir?

- Çalg1 çalmayı öğrenmenin özengen çalg1 eğitimi alan bireylerin sosyal çevrelerine kattığı etkiler nelerdir?

- Çalg1 çalmayı öğrenmenin özengen çalgı eğitimi alan bireylerin müziği meslek edinme düşüncesine etkileri nelerdir? sorularına cevap aranmıştir.

\section{Yöntem}

\section{Araştırma Modeli}

$\mathrm{Bu}$ çalışma nitel araştırma yöntemlerinden durum çalışması olarak desenlenmiştir. Merriam (2015) durum çalışmasını, sınırlı bir sistemin derinlemesine betimlenmesi ve incelenmesi olarak açıklamaktadır. Çalışmada, tek bir analiz birimi olarak özengen çalgı eğitimi ele aldığından durum çalışması türlerinden bütüncül tek durum deseni tercih edilmiştir (Yıldırım ve Şimşek, 2016).

\section{Çalışma Grubu}

Araştırmanın çalışma grubu amaçlı örnekleme yöntemi ile belirlenmiştir. Amaçlı örnekleme yöntemi, araştırmacının kendi kişisel gözlemlerinden hareket ederek araştırma sorunsalına uygun geldiğini düşündüğü belirli özellikleri taşıyan deneklerin seçildiği örneklemedir (Gürbüz ve Şahin, 2016). Bu araştırmada çalışma grubu, Çanakkale ve Balıkesir illerindeki resmî ve özel yaygın eğitim kurumlarında özengen çalgı eğitimi alan 26 katılımcıdan oluşmaktadır. Çalışma grubuna ilişkin demografik bilgiler Tablo 1'de sunulmuştur. Tablo 1'e göre, araştırmaya katılan üniversite öğrencilerinin 14'ünün kadın, 12'sinin erkek olduğu, 15'inin 19-21 yaş, 11'inin 22-25 yaş aralığında olduğu, 13'ünün Çanakkale, 13'ünün ise Balıkesir'de yaşamakta olduğu, 12 'sinin çalg1 eğitimini resmî kurumlarda, 14'ünün ise özel kurumlarda almakta olduğu, 9'unun piyano, 5'inin keman, 5'inin gitar, 3'ünün bağlama, 
2'sinin flüt, 1'inin bateri ve 1'inin de saksafon çalmayı öğrenmekte olduğu ve 3'ünün 4-8 ay, 14'ünün 9-12 ay ve 9'unun da 12-15 ay aralığında çalg1 eğitimi almakta olduğu anlaşılmaktadır.

Tablo 1. Çalışma Grubuna İlișkin Demografik Bilgiler

\begin{tabular}{llc}
\hline & & n \\
\hline Cinsiyet & Kadın & 14 \\
& Erkek & 12 \\
& Toplam & 26 \\
\hline Yaş & 19-21 yaş & 15 \\
& 22-25 yaş & 11 \\
& Toplam & 26 \\
\hline Yaşanılan Şehir & Çanakkale & 13 \\
& Balıesir & 13 \\
& Toplam & 26 \\
\hline Çalgı Eğitimi & Resmî & 12 \\
Alınan Kurum & Özel & 14 \\
Tipi & Toplam & 26 \\
\hline Ĕgitimi Alınan & Piyano & 9 \\
Çalgı & Keman & 5 \\
& Gitar & 5 \\
& Bağlama & 3 \\
& Flüt & 2 \\
& Bateri & 1 \\
& Saksafon & 1 \\
& Toplam & 26 \\
\hline Çalgı Eğitimi & 4-8 ay & 3 \\
& 9-12 ay & 14 \\
& 12-15 ay & 9 \\
& Toplam & 26 \\
\hline
\end{tabular}

\section{Veri Toplama Araci}

Çalışmada veri toplama aracı olarak yarı yapılandırılmış görüşme tekniğinden yararlanılmıştır. Bu görüşme tekniğinde, görüşme öncesi belirlenen soru ve konu başl1kları araştırmacıya rehberlik etmektedir (Gürbüz ve Şahin, 2016). Yarı yapılandırılmış görüşme türü, yöneltilen sorulara sabit seçeneklerle cevap verilmesinin yanında katılımcıların ilgili konuya ilişkin görüşlerini derinlemesine aktarabilmelerine imkân sağlamaktadır (Büyüköztürk, Kılıç, Çakmak, Akgün, Karadeniz ve Demirel, 2016). Bu teknikte araştırmacı görüşme sorularını önceden hazırlar. Ancak araştırmacı görüşme sürecinde kat1lımcılara koşulların durumuna göre bazı esneklikler sağlayabilir. Önceden hazırlamış olduğu soruları yeniden düzenleyebilir ya da sorular hakkında geniş tartışmalara izin verebilir (Çepni, 2012). Bu tür görüşmede, katılımcıların da çalışma üzerinde kontrolleri söz konusudur (Ekiz, 2003). Çalışmanın amacı doğrultusunda araştırmacılar tarafindan hazırlanan görüşme soruları, kapsam 
geçerliğinin sağlanması amacıyla müzik eğitimi alanında uzman 3 öğretim üyesinin görüşlerine sunulmuş ve alınan görüşler değerlendirilerek görüşme formuna son şekli verilmiştir. Nihai form, kişisel bilgiler ile ilgili 6, konu ile ilgili 9 olmak üzere toplam 15 sorudan oluşmaktadır. Görüşme sürecine başlanmadan önce katılımcılara, çalışma ile ilgili bir ön bilgilendirme yapılmış, çalışmaya katılımın gönüllülük esasına dayandığı belirtilmiş ve katılımcılarının onayı alınmıştır. Görüşmeler birebir gerçekleştirilmiş ve her bir görüşme dijital ses dosyası olarak kaydedilmiştir.

\section{Geçerlik ve Güvenirlik}

Çalışmada geçerlik ve güvenirliğin belirlenmesi amacıyla Lincoln ve Guba (1985) tarafından önerilen inandırıcılık, aktarılabilirlik, tutarlık ve teyit edilebilirlik kavramları kullanılmıştır (akt; Yıldırım ve Şimşek, 2016). Çalışmada inandırıcılığın sağlanabilmesi amacıyla uzun süreli etkileşim ve uzman incelemesi yöntemleri tercih edilmiştir. Her bir katılımcı ile 25-30 dakikalık görüşmeler gerçekleştirilmiş ayrıca araştırma konusu ve nitel araştırma yöntemleri konusunda uzman 2 öğretim üyesinden araştırmayı çeşitli boyutlarıyla incelemesi istenmiştir. Aktarılabilirliğin sağlanması amacıyla ayrıntılı betimleme yapılmış ve doğrudan alıntılara yer verilmiştir. Çalışmada tutarlılığın sağlanabilmesi amaciyla Miles ve Huberman (2015)'ın uyum oranı formülünden (Görüş Birliği/(Görüş Birliği+Görüş Ayrılığı)x100) yararlanılmıştır. Uyum oranının \%70 üzerinde bir değere sahip olması verilerin analizinin güvenilir olduğuna işaret etmektedir (Miles ve Huberman, 2015). 2 farklı araştırmacı tarafindan yapılan kodlamalar arasındaki tutarlık toplamda $\% 82$ olarak belirlenmiştir. Çalışmada teyit edilebilirlik ise ulaşılan sonuçların araştırmacı tarafından sürekli olarak ham verilerle karşılaştırılması yoluyla sağlanmaya çalışılmıştır.

\section{Verilerin Analizi}

Çalışmada elde edilen verilerin analizinde içerik analizi yönteminden yararlanılmıştır. Yıldırım ve Şimşek (2016)'in belirttiği gibi içerik analizi, birbirine benzeyen verileri belirli temalar çerçevesinde bir araya getirmek ve bunları anlaşılabilir bir şekilde düzenleyerek yorumlamaktır. Çalışmanın veri analizi merhalesinde Corbin ve Strauss (2008) tarafindan önerilen, verilerin kodlanması, temaların oluşturulması, temaların düzenlenmesi ve bulguların yorumlanması şeklindeki dört basamaklı merhale izlenmiştir. Yarı yapıland1rılmış görüşme tekniği ile elde edilen ve dijital ses dosyası olarak kaydedilen veriler metin olarak bilgisayar ortamına aktarılmıştır. Metinlerden anlamlı bir 
bütün oluşturan bölümler kodlanmış ve bir kod listesi oluşturulmuştur. Kod listesinde benzer özellik gösteren kodlar bir araya getirilerek temalara ulaşılmıştır. Temalar altında toplanan kodlara ilişkin görüş örneklerine Katılımcı 1 (K1), Katılımc1 2 (K2) şeklinde yer verilerek betimsel tablolar oluşturulmuştur.

\section{Bulgular}

Tablo 2. Çalgı Çalmayı Öğrenmenin Kişisel Yaşantı Üzerindeki Etkileri TEMA: KişiSISEL YAŞANTI

\begin{tabular}{|c|c|c|}
\hline Katego & i Kodlar & Görüş Örnekleri \\
\hline \multirow{6}{*}{ 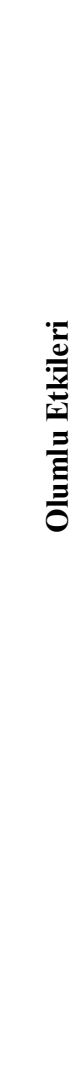 } & $\begin{array}{l}\text { Zamanı verimli } \\
\text { değerlendirme }\end{array}$ & $\begin{array}{l}\text { "Çalgı çalmayı öğrenmeye zaman ayırmak, günlük plan prog- } \\
\text { ram yapmamı ve saatlerimi iyi organize etmemi sağlıyor." (K3) } \\
\text { "Bilgisayar oynayacağıma çalgl çalı̧̧ıyorum. Bu da vaktimi ve- } \\
\text { rimli ve değerli kullanmamı sağllyor." (K12) }\end{array}$ \\
\hline & $\begin{array}{l}\text { Hayata karşı } \\
\text { bakış açısını } \\
\text { geliştirme }\end{array}$ & $\begin{array}{l}\text { "Sağllk problemlerimden kaynaklanan rahatsılıklarım oluyor } \\
\text { ancak çalgı çalarak bu konuda kendimi motive ediyorum. Daha } \\
\text { pozitif oluyorum." (K16) }\end{array}$ \\
\hline & $\begin{array}{l}\text { Sosyal hayata } \\
\text { katkı sağlama }\end{array}$ & $\begin{array}{l}\text { "Çalgl çalabildiğim için sosyal ortamlarda ön planda oldu- } \\
\text { ğumu hissediyorum." (K8) } \\
\text { "Müzikle uğraşan kişilerden oluşan bir sosyal hayatım oldu." } \\
\text { (K10) }\end{array}$ \\
\hline & $\begin{array}{l}\text { Müzikal } \\
\text { yaşantıyı } \\
\text { geliştirme }\end{array}$ & $\begin{array}{l}\text { "Çalgı çalmayı öğrenmenin yanında müzik ile ilgili birçok bil- } \\
\text { giyi de öğreniyorum. Böylece kendime müzik açısından bir ya- } \\
\text { şantı oluşturmuş oluyorum.” (K3) } \\
\text { "Çalgı çalmayı öğrenmek müzik zevkimin gelişmesini sağlıyor. } \\
\text { Müzik konusunda daha bilgili olduğumu hissediyorum.” (K18) }\end{array}$ \\
\hline & $\begin{array}{l}\text { Hayatın } \\
\text { yoğunluğundan } \\
\text { uzaklaşmayı } \\
\text { sağlama }\end{array}$ & $\begin{array}{l}\text { "Çalmak işimin verdiği stresi benden alıyor, o yüzden olumlu." } \\
\text { (K5) } \\
\text { "Genellikle yoğun bir tempoda ders çalıştığım için bağlama çal- } \\
\text { mak bana nefes almak için bir alan oluşturuyor." (K9) }\end{array}$ \\
\hline & $\begin{array}{l}\text { Fiziksel ve ruhsal } \\
\text { gelişimi } \\
\text { destekleme }\end{array}$ & $\begin{array}{l}\text { "Çalgı çalmak kendimi daha mutlu ve enerjik hissetmeme neden } \\
\text { oluyor." (K12) } \\
\text { "Ruhuma hitap ettiğini düşünüyorum. Çünkü çaldı̆̆ım parça- } \\
\text { larda birçok duyguyu hissedebiliyorum." (K17) } \\
\text { "El-kol koordinasyonumun geliştiğini hissediyorum. Bu da fi- } \\
\text { ziksel gelişim olarak bana katkı sağllyor." (K24) }\end{array}$ \\
\hline \multirow{3}{*}{ 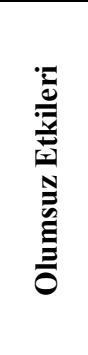 } & $\begin{array}{l}\text { İhtiyaçları } \\
\text { erteleme } \\
\text { zorunluluğu }\end{array}$ & $\begin{array}{l}\text { "Bazen çalgı dersine yetişmek için okuldaki derslerimden çıkar } \\
\text { çıkmaz geliyorum ve firsatım olmadı̆̆ için yemek yemeden } \\
\text { derse giriyorum." (K1) } \\
\text { "Bazen işim gereği nöbete kallyorum ve nöbet çıkışı uykusuz ge- } \\
\text { liyorum derse." (K13) }\end{array}$ \\
\hline & Zaman alma & $\begin{array}{l}\text { "Bazen çalgı öğrenmeye ayırdı̆̆ım zaman yüzünden diğer yap- } \\
\text { mam gereken işleri yetiştiremiyorum." (K2) }\end{array}$ \\
\hline & $\begin{array}{l}\text { Akademik } \\
\text { yaşantıyı etkileme }\end{array}$ & $\begin{array}{l}\text { "Ders çalışmam gereken zamanı çalgı çalarak geçirdiğimde } \\
\text { derslerimi etkiliyor bazen." (K15) }\end{array}$ \\
\hline
\end{tabular}


Tablo 2'de çalg1 çalmayı öğrenmenin kişisel yaşantı üzerindeki etkilerine ilişkin kodlara yer verilmiştir. Bu kodlar olumlu etkiler ve olumsuz etkiler kategorileri ve kişisel yaşantı teması adı altında sınıflandırılmıştır. Katılımcılardan elde edilen görüşler, çalgı çalmayı öğrenmenin olumlu etkilerine ilişkin olarak zamanı verimli değerlendirme, hayata karşı bakış açısını geliştirme, sosyal hayata katkı sağlama, müzikal yaşantıyı geliştirme, hayatın yoğunluğundan uzaklaşmayı sağlama ve fiziksel ve ruhsal gelişimi destekleme kodları ile belirtilmiştir. Çalgı çalmayı öğrenmenin olumsuz etkileri kategorisine ilişkin görüşler ise ihtiyaçları erteleme zorunluluğu, zaman alma ve akademik yaşantıyı etkileme kodlarıyla sınıflandırılmıştır. Ayrıca tabloda, kodlara ait katılımcı görüşlerine alıntı olarak yer verilmiştir.

Tablo 3. Çalgı Çalmayı Öğrenmenin Sosyal Çevre Üzerindeki Etkileri

\begin{tabular}{|c|c|c|}
\hline Kategori & Kodlar & Görüş Örnekleri \\
\hline \multirow{4}{*}{ 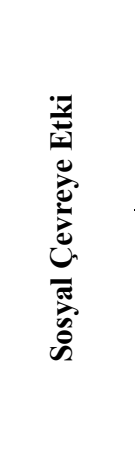 } & \multirow{2}{*}{$\begin{array}{l}\text { Sosyal } \\
\text { çevrede çalg1 } \\
\text { çalma merak1 } \\
\text { oluşturma }\end{array}$} & $\begin{array}{l}\text { "Arkadaşlarımdan biri nasıl öğrendiğimi ve nerede eğitim al- } \\
\text { dığımı sordu. Bir başka arkadaşım da beni dinledikten sonra } \\
\text { 'ben de mi başlasam güzel bir çalglya benziyor' dedi." (K2) }\end{array}$ \\
\hline & & $\begin{array}{l}\text { "Beni dinledikten sonra bir arkadaşım çalgı ögrenmeye baş- } \\
\text { ladl. Hatta şu an o kişiyle birlikte müzik yapıyoruz." (K11) }\end{array}$ \\
\hline & \multirow{2}{*}{$\begin{array}{l}\text { Çalg1 çalmak } \\
\text { isteyen } \\
\text { bireyleri } \\
\text { yönlendirme }\end{array}$} & $\begin{array}{l}\text { "Okuldan ilgi duyan arkadaşlarım oldu. Nasll ve nerede ĕ̌i- } \\
\text { tim alacakları konusunda onlara yardımcı oldum. Hatta bir } \\
\text { arkadaşıma bagetlerimi hediye ettim." (K19) }\end{array}$ \\
\hline & & $\begin{array}{l}\text { "Hoşlanan arkadaşlarıma çaldıklarımın videosunu gönderi- } \\
\text { yorum. İlgi duyup ögrenmek isteyen arkadaşlarıma da yol gös- } \\
\text { termeye çalışıyorum." (K8) }\end{array}$ \\
\hline
\end{tabular}

Tablo 3'te çalgı çalmayı öğrenmenin sosyal çevre üzerindeki etkileri sosyal çevre teması ve sosyal çevreye etki kategorisi altında sunulmuştur. Katılımcıların ifadelerinden yola çıkılarak oluşturulan kodlar sosyal çevrede çalg1 çalma merakı oluşturma ve çalg1 çalmak isteyen bireyleri yönlendirme başlıkları altında katılımcılardan elde edilen görüşlerle birlikte sunulmuștur.

Tablo 4'te çalgı çalmayı öğrenmeye yönelik güdülenme, güdülenme teması altında içsel güdülenme ve dışsal güdülenme kategorileri altındaki kodlarla açıklanmıştır. Katılımcılar içsel güdülenme ile ilgili olarak fedakârlık anlayışı geliştirme, müziğe ve çalgı çalmaya ilgi duyma, dinlenilen parçaları çalabilme isteği, bir beceri edinme isteği, müziği meslek edinme isteği ve kendini ayrıcalıklı hissetme isteği kodlarına yönelik ifadelerde bulunmuşlardır. 
Tablo 4. Çalgı Çalmayı Öğrenmeye Yönelik Güdülenme TEMA: GÜDÜLENME

\begin{tabular}{|c|c|c|}
\hline \multicolumn{2}{|c|}{ Kategori Kodlar } & \multirow[b]{2}{*}{$\begin{array}{l}\text { Görüş Örnekleri } \\
\text { "Arkadaşlarımla buluşmak durumunda olsam ya da başka bir } \\
\text { işim olsa bile bağlama kursunu hiçbir zaman aksatmıyorum. Önce } \\
\text { kursa gidiyorum sonra diğer işlerime zaman ayırıyorum. Bence } \\
\text { bu bir fedakârlı ancak hiç şikâyetçi değilim." (K3) } \\
\text { "Ailemle vakit geçirmem gereken zamanları çoğu zaman çalgıya } \\
\text { ayırıyorum. Ama bunu olumsuz olarak görmüyorum. Sonuçta } \\
\text { çalgl öğrenebilmek için zaman zaman bazı şeylerden fedakârlı } \\
\text { yapmak gerekiyor." (K18) }\end{array}$} \\
\hline \multirow{6}{*}{ 兽 } & $\begin{array}{l}\text { Fedakârlık } \\
\text { anlayışı } \\
\text { geliştirme }\end{array}$ & \\
\hline & $\begin{array}{l}\text { Müziğe ve çalg1 } \\
\text { çalmaya ilgi } \\
\text { duyma }\end{array}$ & $\begin{array}{l}\text { "Müziğ ve çalgı çalmaya uzun zamandır ilgi duyuyordum. Bu ne- } \\
\text { denle çalgl eğitimi almak istedim." (K2) } \\
\text { "Küçüklügüumden beri hep çalgı çalmak isterdim. Çalgı çalmak en } \\
\text { büyük hayallerimden biriydi. Şu an hayallerimden birini gerçek- } \\
\text { leştiriyorum." (K24) }\end{array}$ \\
\hline & $\begin{array}{l}\text { Dinlenilen } \\
\text { parçaları } \\
\text { çalabilme isteği }\end{array}$ & $\begin{array}{l}\text { "Çalgı çalmaya başlamadan önce hep türkü dinlerdim ve dinledi- } \\
\text { ģim türküleri çalmak isterdim. Bu durum beni çalgı ögrenmeye } \\
\text { yönlendirdi." (K1) } \\
\text { "Rock müzik dinliyorum genelde ve bu müziğe uygun bir çalgl çal- } \\
\text { mak istedim." (K20) }\end{array}$ \\
\hline & $\begin{array}{l}\text { Bir beceri edinme } \\
\text { isteği }\end{array}$ & $\begin{array}{l}\text { "Çalgı çalabilmeyi bir beceri olarak görüyorum. Çalgı çalmaya } \\
\text { ilgim vardl ve bir beceri edinmek istedim." (K14) }\end{array}$ \\
\hline & $\begin{array}{l}\text { Müziği meslek } \\
\text { edinme isteği }\end{array}$ & $\begin{array}{l}\text { "Üniversitede müzik öğretmenliğinde okuma istiyorum. Bu ne- } \\
\text { denle üniversiteye hazırlı olması açısından çalgı ögrrenmeye baş- } \\
\text { ladım." (K6) } \\
\text { "Müzik alanında ilerlemek ve müziği meslek edinmek istiyorum. } \\
\text { Bunun için de çalgl çalabilmeyi önemli görüyorum.” (K14) }\end{array}$ \\
\hline & $\begin{array}{l}\text { Kendini ayrıcalıklı } \\
\text { hissetme isteği }\end{array}$ & $\begin{array}{l}\text { "Çalgl çalan insanların farklı olduğunu ve ilgi çektiklerini düşü- } \\
\text { nüyorum. Ben de bu farklılığ hissetmek istedim." (K4) }\end{array}$ \\
\hline \multirow{5}{*}{ 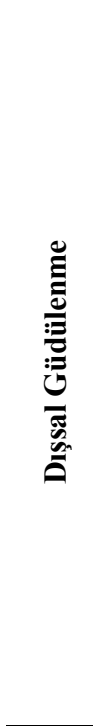 } & $\begin{array}{l}\text { Aile ve } \\
\text { arkadaşların } \\
\text { çalgı öğrenmeyi } \\
\text { desteklemesi }\end{array}$ & $\begin{array}{l}\text { "Çevremdeki insanlara çaldiğımda beğeniyorlar ve zamanla daha } \\
\text { da ilerletebileceğimi söylüyorlar. Aileme çaldığımda daha fazla } \\
\text { çalsana gibi tepkiler alıyorum. Desteklerini hissediyorum hep." } \\
(\mathrm{K} 2) \\
\text { "Hep bağlama çalmayı istiyordum. Sadece ben değil ailemde çok } \\
\text { istiyordu. Benim isteğimin yanında ailem de ögrenmeme olumlu } \\
\text { baktı hep." (K10) }\end{array}$ \\
\hline & $\begin{array}{l}\text { Çevrenin ilgisini } \\
\text { hissetme }\end{array}$ & $\begin{array}{l}\text { "Çevremdeki kişilere çalgı çaldı̆̆ımda beğendikleri için çok mutlu } \\
\text { oluyorum ve o zaman çalma isteğim daha çok artıyor." (K1) } \\
\text { "Çalgı çaldığımda çevremdekilerin ilgisini üzerimde hissetmek } \\
\text { bana büyük keyif veriyor. Öyle olunca da hep çalmak istiyorum." } \\
\text { (K2) }\end{array}$ \\
\hline & $\begin{array}{l}\text { Ailenin gurur } \\
\text { duymas1 }\end{array}$ & $\begin{array}{l}\text { "Ailem her firsatta çevremizdeki kişilere çalgı çaldığımı söylüyor. } \\
\text { Benimle gurur duyuyorlar." (K10) }\end{array}$ \\
\hline & $\begin{array}{l}\text { Ailenin dinlediği } \\
\text { müzik türlerinden } \\
\text { etkilenme }\end{array}$ & $\begin{array}{l}\text { "Küçüklüğümden beri annem çok türkü dinlerdi evde. Bende onun } \\
\text { dinlediği türküleri duyarak etkilendim ve kendi kültürümüzün bir } \\
\text { parçası da olduğu için bağlama öğrenmek istedim." (K9) }\end{array}$ \\
\hline & $\begin{array}{l}\text { Çalgı hediye } \\
\text { edilmesi }\end{array}$ & $\begin{array}{l}\text { "Amcamın bana keman hediye etmesi ile keman öğrenmeye baş- } \\
\text { ladım. Benim için manevi bir değeri var. O yüzden öğreniyorum." } \\
\text { (K13) }\end{array}$ \\
\hline
\end{tabular}


Dışsal güdülenme kategorisinde yer alan kodlar ise aile ve arkadaşların çalg1 öğrenmeyi desteklemesi, çevrenin ilgisini hissetme, ailenin gurur duyması, ailenin dinlediği müzik türlerinden etkilenme ve çalgı hediye edilmesi şeklinde adlandırılmıştır.

Tablo 5'te çalg1 çalmayı öğrenmeye yönelik olarak tutum teması adı altındaki görüşlere yer verilmiş görüşlerin tümünün olumlu tutumları içermesi nedeniyle kodlar olumlu tutumlar kategorisi altında sunulmuştur. Tablo 4'te yer alan katılımcı görüşlerinden yola çıkılarak oluşturulan kodlar, çalgı çalmayı öğrenmekten mutluluk duyma, çalgı çalmanın rahatlatıcı etkisi ve çalgı çalmayı başarabilme inancı olarak sınıflandırılmıştır.

Tablo 5. Çalgı Çalmayı Öğrenmeye Yönelik Tutum

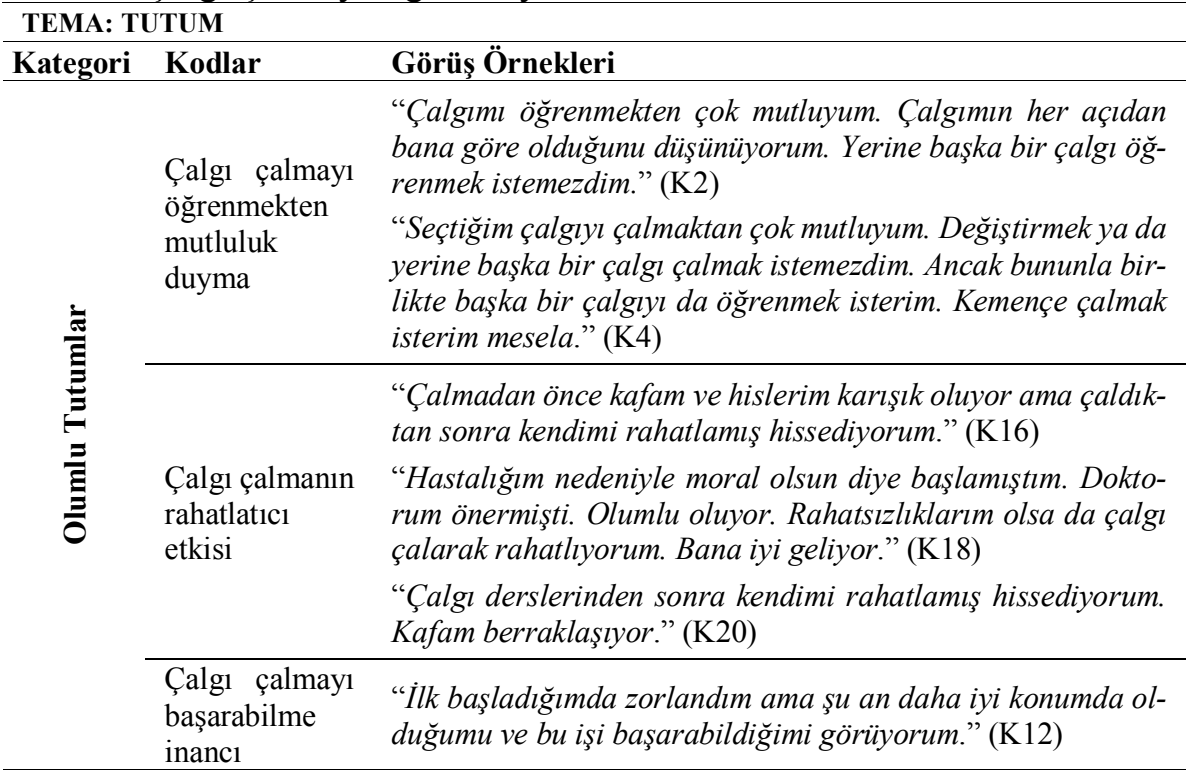

Tablo 6'da çalg1 çalmayı öğrenmeye yönelik öz yeterlilik ifadelerine yer verilmiş ve bu ifadeler öz yeterlik inancı temasına bağlı olarak kendine güvenme ve kaygı duyma kategorileri altında sunulmuştur. Tablodan da anlaş1lacağı gibi kendine güvenme kategorisi altında başka bir çalgıyı da çalabilmeye inanma, çalgı çalmaya ilişkin gurur duyma ve çalgı çalmaya ilişkin özgüven, kaygı duyma kategorisi altında da çalarken heyecanlanma ve çalarken hata yapmaktan korkma kodları katılımcıların görüş örnekleriyle birlikte sunulmuştur. 
Tablo 6. Çalgı Çalmayı Öğrenmeye Yönelik Öz Yeterlik İnancı TEMA: ÖZ YETERLIK INNANCI Kategori Kodlar Görüş Örnekleri

"Çalgımı ilerleyen süreçte daha da iyi çalabileceğime inantyorum. Bu nedenle başka bir çalgı da ögrrenmek isterim. Me-

Başka bir çalgıyı da çalabilmeye sela kü̧ükken piyano çalmayı çok istiyordum. Hâla da öğinanma renebilirim." (K10)

“İlk başladı̆̆ımda çalgı çalmak zor geldi ama şu an başarabildiğime inanıyorum. O nedenle bu çalgının yanında piyano da öğrenmek istiyorum." (K12)

“Özellikle çevremdeki insanlara çaldığımda ilgiyi üstümde hissediyorum. Tipk bir gruba öncülük etmek gibi. Bu beni

Çalgı çalmaya çok mutlu ediyor. Başarma duygusunu tadıyorum. Başarailişkin gurur bildiğim için de kendimle gurur duyuyorum." (K2)

duyma

"Çalgımı çevremdeki insanlara çaldığımda olumlu tepkiler alıyorum. Bu da çalgı çaldığım için kendimi iyi hissetmemi ve kendimle gurur duymamı sağllyor." (K4)

Çalgı çalmaya

"İstediğiniz ve sevdiğiniz bir işi yapmanın verdiği duygu çok ilişkin özgüven güzel. Çalgl çalmak bana özgüven veriyor." (K11)

"Çaldiğımda insanların beğenmesi ve bana güzel şeyler söylemesi özgüvenimi arttırlyor.” (K20)

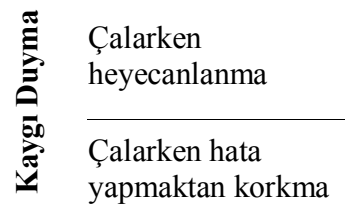

"Sevdiğim ve güzel çaldığım parçaları çalarken kendimi iyi hissediyorum. Ancak genelde çalarken kasıllyorum ve heyecan yapıyorum." (K9)

\section{"Çalarken biraz korkuyorum. Yanlış çalma endişesi oluyor.} Ama parça bitince bir sıkıntım kalmıyor." (K7)

Tablo 7. Çalgı Çalmayı Öğrenmeye Yönelik Üstbiliş

\section{TEMA: ÜSTBÍLiş̧}

Kategori Kodlar

Örenmeye

başlamadan önce çalgı çalmanın zor olduğunu düşünmeme

\section{Görüş Örnekleri}

"Öğrenmeye başlamadan önce kısa sürede Erdal Erzincan gibi çalabileceğimi düşünüyordum ancak öğrenmeye başlayınca o kadar da kolay olmadı̆̆ını farkettim." (K1)

“Ögrenmeye başlamadan önce bu kadar emek ve ciddiyet gerektiren bir uğraşs olduğunu düşünmüyordum. Bu nedenle ögrenemeye başladiktan sonra bu durum beni biraz zorladı." (K18)

Öğrenmeye başlama- “Öğrenmeye başlamadan önce çalgı çalan kişileri izlerken dan önce çalg1 çalmanın zor çok zor bir uğraş olduğunu düşünüyordum. Ancak öğrenolduğunu düşünme meye başladıktan sonra yapamayacağım bir iş olmadığının farkına vardım." (K2)

İlk defa çalışılacak bir parçada zorluk yaşama

"Etüd ya da eser olsun ilk defa çalacağım bir parçayı öğrenmeye başladığımda zorluk yaşıyorum." (K16)

"İlk defa çalışacağım parçalarda zorlanıyorum ama parçayı anladıkça bu zorluk ortadan kalkıyor.” (K25) 
Tablo 7'de çalgı çalmayı öğrenmeye yönelik üstbiliş ifadelerine yer verilmiş ve bu ifadeler üstbiliş teması kapsamında üstbilişsel farkındalık kategorisinde sunulmuştur. Tablodan da anlaşılacağı gibi üstbilişsel farkındalık kategorisi altında öğrenmeye başlamadan önce çalgı çalmanın zor olduğunu düşünmeme, öğrenmeye başlamadan önce çalgı çalmanın zor olduğunu düşünme ve ilk defa çalışılacak bir parçada zorluk yaşama kodları yer almaktadır.

Tablo 8'de çalgı çalmanın müziği meslek edinme düşüncesi üzerindeki etkileri meslek edinme teması ve müziği meslek edinme düşüncesi kategorisi altında yer alan kodlar aracılığı ile sunulmuştur. Tabloya göre, katılımcılardan elde edilen görüşlerin müziği hobi olarak görme, meslek hâline getirmeyi geçmişe dönük olarak arzulama ve meslek hâline getirmek isteme kodları altında toplandığı anlaşılmaktadır.

Tablo 8. Çalgı Çalmayı Öğrenmenin Müziği Meslek Edinme Düşüncesi Üzerindeki Etkileri

\section{TEMA: MESLEK EDINME}

\begin{tabular}{|c|c|c|}
\hline Kategori & Kodlar & Görüş Örnekleri \\
\hline \multirow{5}{*}{ 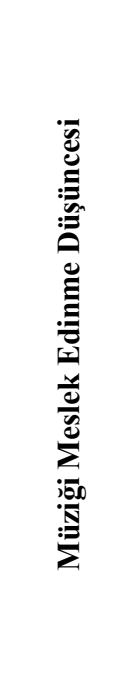 } & \multirow{2}{*}{ Hobi olarak görme } & $\begin{array}{l}\text { "Çalgı öğrenmeye hobi edinmek amact ile başladım. Öyle } \\
\text { de devam edeceğini düşünüyorum. Çünkü kendimi müziği } \\
\text { meslek edinecek düzeyde yetenekli bulmuyorum." (K2) }\end{array}$ \\
\hline & & $\begin{array}{l}\text { "Çalgı çalmayl, gelecekte edineceğim esas mesleğimin ya- } \\
\text { nında beni ayrıcalıklı kllacak bir hobi olarak görüyorum." } \\
\text { (K7) }\end{array}$ \\
\hline & $\begin{array}{l}\text { Meslek hâline getir- } \\
\text { meyi geçmişe } \\
\text { dönük olarak } \\
\text { arzulama (Keşke) }\end{array}$ & $\begin{array}{l}\text { "Çalgı öğrenmeye daha genç yaşta başlamış olsaydım } \\
\text { mutlaka meslek edinmek isterdim. Ama kendimi bu işe geç } \\
\text { kalmıs olarak görüyorum. Bu nedenle bu iş benim için yal- } \\
\text { nızca bir hobi." (K5) }\end{array}$ \\
\hline & \multirow{2}{*}{$\begin{array}{l}\text { Meslek hâline } \\
\text { getirmek isteme }\end{array}$} & $\begin{array}{l}\text { "Üniversitede müzik eğitimi almak ve müziği meslek edin- } \\
\text { mek istiyorum. Bu hayalimi gerçekleştirmek için şimdiden } \\
\text { bir çalgl ögrenmeye başladım." (K6) }\end{array}$ \\
\hline & & $\begin{array}{l}\text { "Çalgı öğrenmek çok ciddi bir iş bunu profesyonel olarak } \\
\text { başarabilir miyim bilmiyorum. Ancak müziği meslek edin- } \\
\text { meyi çok istiyorum. Bu nedenle de elimden geleni yapmaya } \\
\text { çalışacağım." (K18) }\end{array}$ \\
\hline
\end{tabular}

\section{Sonuç, Tartışma ve Öneriler}

Özengen çalg1 eğitimi alan bireylerin çalg1 çalmayı öğrenmeye yönelik görüşlerinin belirlenmesi amacını taşıyan bu çalışmanın sonuçları doğrultusunda, çalgı çalmayı öğrenmenin bireylerin kişisel yaşantı, sosyal çevre ve müziği meslek edinme düşüncesi üzerinde etkili olduğu sonucuna ulaşılmıştır. Diğer yandan özengen çalg1 eğitimi alan bireylerin görüşlerinden yola çıkıla- 
rak güdülenme, tutum, öz yeterlik inancı ve üstbilişsel farkındalığın çalgı çalmayı öğrenme ile yakından ilişkili olduğu belirlenmiştir.

Lehr (1998)'e göre müzik, bireylerin yaşantılarını etkileyen ve yaşantılardan etkilenen, bireylerin becerilerini geliştirerek akademik, kültürel ve sosyal alanlarda daha başarılı olmalarına katkı sağlayan bir araçtır (akt; Kılıç, 2007). Bu bağlamda çalışmadan elde edilen sonuçlar doğrultusunda da çalgı çalmayı öğrenmenin kişisel yaşantı açısından, zamanı verimli değerlendirebilme, hayata karşı bakış açısını geliştirme, iş, akademik ve sosyal hayata katkı sağlama, müzikal yaşantıyı geliştirme, hayatın yoğunluğundan uzaklaşmayı sağlama ve fiziksel gelişimi destekleme gibi olumlu etkiler taşıdığı belirlenmiştir. Diğer yandan çalışmanın sonuçlarına göre, çalg1 çalmayı öğrenmek özengen müzik eğitimi alan bireylerin kişisel yaşantılarında bazı olumsuz etkilere de neden olabilmektedir. Kişisel yaşantı içinde çalg1 çalmayı öğrenebilmek için ayrılan zaman, bazı fiziksel ihtiyaçların ertelenme zorunluluğunu ve akademik yaşantının yine zaman açısından etkilenmesini beraberinde getirmektedir. Özengen müzik eğitiminin meslekî müzik eğitiminden farklı olarak bireylerin ilgi ve zevkleri doğrultusunda iş-akademik ve sosyal yaşantılarından zaman ayırarak aldıkları bir eğitim olduğu düşünüldüğünde bazı olumsuz etkilerle de karşılaşılması olağan gözükmektedir. Ancak bu gibi durumların bireyin çalgı çalmayı öğrenmeye yönelik ilgisinin önüne geçmemesi çalgı eğitiminin sekteye uğramasına sebep olmamaktadır.

Çalg1 çalmayı öğrenmenin kişisel yaşantı dışında sosyal çevre üzerinde de büyük bir etkisinin olduğu bilinen bir gerçektir. Örneğin Türkmen (2010) amatör müzik eğitiminin arkadaşlık ilişkilerinin geliştirilmesi, bireylerin toplumsal yönlerinin güçlendirilmesi ve bireyler arasındaki ilişkilerin sağlıklı bir şekil almasında önemli bir rol oynadığını vurgulamaktadır. Bulgular doğrultusunda da özengen çalg1 eğitiminin sosyal çevrede merak oluşturduğu ve çevredeki bireyleri çalg1 eğitimi almaya yönlendirebildiği sonucuna ulaşılmıştır.

Çalışmanın en önemli sonuçlarından birini çalgı çalmayı öğrenme ve güdülenme ilişkisi oluşturmaktadır. Katılımcıların çalgı çalmayı öğrenme süreci ile ilgili olarak içsel ve dişsal güdülenmelerden etkilendikleri sonucuna varılmıştır. Öğretim faaliyetlerinin gerçekleşmesinde en önemli öğelerden birini güdülenme oluşturmaktadır. Eğitim açısından güdülenme, öğrencilerin potansiyellerini açığa çıkaran, öğrenme ve çalışmaları harekete geçiren güç olarak açıklanmaktadır (Martin, 2004). Güdülenme içsel ve dışsal olarak iki 
açıdan düşünülmektedir. Öğrenmeye ilgi duyma, geliştiğini hissetme ve başarma duygusu içsel güdülenmeyi oluşturan etmenlerdir. Bireyin diğer bireyler tarafından takdir edilmesi, çevredeki bireylerin ilgisini hissetme ve ödül kazanma gibi etmenler de dışsal güdülenmeyi oluşturmaktadır (Ryan ve Deci, 2000). Çalışmadan elde edilen bulgular doğrultusunda katılımcıların çalgı çalmayı öğrenmeye yönelik olarak müziğe ve çalgı çalmaya ilgi duyma, beceri edinme, müziği meslek edinme ve kendini ayrıcalıklı hissetme isteği gibi içsel güdülenmelere; aile ve arkadaşların çalgı öğrenmeyi desteklemesi, çevrenin ilgisini hissetme ve ailenin gurur duyması gibi de dışsal güdülenmelere sahip oldukları soncuna varılmıştır.

Çalışmadan elde edilen bir diğer sonuç da çalgı çalmayı öğrenme ve tutum ilişkisidir. Thurstone (1931)'a göre tutum psikolojik bir objeye yönelen olumlu ya da olumsuz bir yoğunluk sıralamasıdır ve tutumlar bireylerin duygu, düşünce ve davranışları ile bütünlük içindedir (akt; Tavşancıl, 2006). Elde edilen görüşler doğrultusunda katılımcıların çalgı çalmayı öğrenmeye yönelik olarak olumlu tutumlara sahip oldukları belirlenmiştir. Bireylerin çalgı çalmaktan mutlu olma, çalgı çalmayı rahatlatıcı bir eylem olarak görme ve çalgı çalmayı başarabildiklerine inanma gibi olumlu tutumlarının özengen çalgı eğitiminde ilgi, başarı ve sürekliliği beraberinde getireceği düşünülmektedir.

Bir diğer yandan çalışmada özyeterlilik açısından kendine güvenme ve kaygı duyma gibi düşünce ve hislerin de çalgı çalmayı öğrenme ile ilişkili olduğu belirlenmiştir. Bandura'nın Sosyal Öğrenme Kuramı'na dayanan özyeterlik, bireyin farklı durumlarla baş etme, belli bir performansı göstermek için gerekli etkinlikleri düzenleyip başarılı olma kapasitesi hakkında kendi algılayış1, inanc1 ve yargısıdır (Gürcan, 2005). Bu doğrultuda özengen çalg1 eğitimi alan bireylerin özyeterlik açısından çalgı çalmaya yönelik inanç, gurur duyma, özgüven, heyecan ya da hata yapmaktan korkma gibi duygu ve düşünceler taşıdıkları saptanmıştır.

Çalışmada özengen çalg1 eğitimi alan bireylerin çalg1 eğitimlerine başlamadan önce çalgı çalmanın zor ya da kolay olduğuna ilişkin üstbiliş geliştirdikleri ayrıca ilk defa çalışacakları bir parçada zorluk yaşadıklarının bilincinde oldukları saptanmıştır. Bu durumu Pintrich (2002) üstbilişsel bilgide kişinin kendine dönük öz bilgisi olarak açıklamaktadır. Katılımcılardan elde edilen bu görüşler, katılımcıların çalgı çalmayı öğrenmeye yönelik bir farkındalığa ve üstbiliş açısından kendilerine dönük bir öz bilgiye sahip olduklarını 
göstermektedir.

Uçan (1997)'ın tanımına göre özengen müzik eğitimi müziğe ilgisi, isteği ve yeteneği olup müziği kendisi için bir hobi olarak seçenlere yöneliktir. Bu bağlamda özengen müzik eğitimi alan bireylerin müziği meslek edinmenin dışında genellikle bir hobi, uğraş olarak sürdürmeleri amaçlanır. Ancak günümüzde özengen müzik eğitimi alan bireylerin müziği hobi dışında meslek edinmeye yönelik bir basamak olarak da görmeleri mümkündür. Müzik öğretmenliği programlarına hazırlanan bireylerin özel dersler ya da kurslar aracılığ ile özengen müzik eğitimi almaları buna örnek olarak gösterilebilir. Diğer yandan yaşantısının herhangi bir döneminde müziği meslek edinmek istemiş ancak çeşitli nedenlerle başaramamış bireylerin de müzik etkinliklerini özengen müzik eğitimi yoluyla gerçekleştirmeye çalıştıkları karşılaşılan bir durumdur.

$\mathrm{Bu}$ çalışmadan yola çıkılarak özengen çalg1 eğitimi ile ilgili olarak:

- Özengen çalg1 eğitimi sürecinde müziği meslek edinmeye karar veren bireyler ile bu eğitimi hobi olarak sürdürmeyi planlayan bireylerin çalgı çalmayı öğrenmeye yönelik düşünce ve davranışları farklı boyutlar açısından karşılaştırılabilir.

- Çalışmada özengen çalgı eğitiminin güdülenme, tutum, öz yeterlik ve üstbiliş ile yakından ilişkili olduğu saptanmıştır. Bu bağlamda bu kavramların özellikle özengen çalg1 eğitiminde ölçülebileceği ölçme araçları geliştirilebilir.

- Özengen çalgı eğitimi açısından nitel ve nicel ölçme araçlarının birlikte kullanıldığı karma desen çalışmalara da yer verilebilir.

\section{Kaynakça}

Bingöl, F. (2010). Özengen gitar eğitiminde parmak hazırlamalı ögretim yönteminin ögrrencilerin gitar çalmadaki başarılarına etkisi (Özel Çağlar Müzik Kursu örneği). Yayımlanmamış doktora tezi, Gazi Üniversitesi Eğitim Bilimleri Enstitüsü.

Büyüköztürk, Ş., Kılı̧̧-Çakmak, E., Akgün, Ö. E., Karadeniz, Ş. ve Demirel, F. (2016). Bilimsel araştırma yöntemleri (22. baskı). Ankara: Pegem Akademi.

Cope, P. (2002) Informal learning of musical instruments: the importance of social context. Music Education Research, 4(1), 93-104.

Corbin, J. ve Strauss, A. (2008). Basics of qualitative research: Techniques and procedures for developing grounded theory (3. bask1). Thousand Oaks, CA, US: Sage Publications, Inc.

Çağlar, E. (2011). Özengen keman eğitimi alan ögrencilerin temel hedeflere erişme 
düzeylerinin çeşitli değişkenler açısından incelenmesi (bir müzik kursu örneği). Yayımlanmamış doktora tezi, Gazi Üniversitesi Eğitim Bilimleri Enstitüsü.

Çağlar, E. (2017). Türkiye'de özengen (amatör) keman eğitimi alanında görev yapan eğitimcilerin keman derslerine ilişkin görüşlerinin değerlendirilmesi: Ankara ili örneği. Journal of Current Researches on Educational Studies, 7(2), 113124.

Çepni, S. (2012). Araştırma ve proje çalışmalarına giriş. Trabzon: Celepler Matbaac1lik.

Davidson, J. ve Jordan, N. (2007). Private teaching, private learning- An explotarion of music instrument learning in the private studio, junior and senior conservatories. Bresler, L., (Ed.), International handbook of research in arts education içinde (729-744). Dordrecht: Springer.

Ekiz, D. (2003). Eğitimde araştırma yöntem ve metodlarına giriş. Ankara: Anı Yayincilik.

Güleç, V. (2018). Özengen müzik ĕgitimi veren kurumlarda klarnet ĕgitimine yönelik ögretmen görüşleri (Ankara ili örneği). Yayımlanmamış yüksek lisans tezi, Gazi Üniversitesi Eğitim Bilimleri Enstitüsü.

Gürbüz, S. ve Şahin, F. (2016). Sosyal bilimlerde araştırma yöntemleri (3. baskı). Ankara: Seçkin Yayıncılık.

Gürcan, A. (2005). Bilgisayar özyeterliği algısı ile bilişsel öğrenme stratejileri arasındaki ilişki. Eğitim Araştırmaları Dergisi, 19, 179-193.

Hancıoğlu, G. (2010). Ankara'daki özengen (amatör) müzik ĕgitimi veren kurumların eğitim anlayışları ve yönetim biçimleri üzerine genel bir inceleme. Yayımlanmamış yüksek lisans tezi, Gazi Üniversitesi Eğitim Bilimleri Enstitüsü.

İmik, Ü. ve Dönmez, Y. E. (2017). Özengen müzik eğitimi veren kurumlarda Türk müziği ilgisi: Malatya örneği. Inönü Üniversitesi Kültür ve Sanat Dergisi, 3(2), 114-128.

Jentzsch, I., Mkrtchian, A. ve Kansal, N. (2014). Improved effectiveness of performance monitoring in amateur instrumental musicians. Neuropsychologia, 52, 117-124.

Karakoç, E. ve Şendurur, Y. (2015). İlköğretim okullarındaki özengen müzik eğitiminin öğrencilerin müziksel davranışlarına yansıması. Çankırı Karatekin Üniversitesi Sosyal Bilimler Enstitüsü Dergisi, 6(1), 277-290.

Karan, M. (2011). Özengen müzik ĕ̌itimi veren kurumlarda çalgl ĕgitimi alan öğrencilerin mesleki yönelimlerinin incelenmesi. Yayımlanmamış yüksek lisans tezi, Gazi Üniversitesi Eğitim Bilimleri Enstitüsü.

Kılıç, T. (2007, Eylül). Müziğin kişisel, toplumsal, ulusal ve uluslararast işlevlerinin müzik eğitimine etkileri. 38. Uluslararası Asya ve Kuzey Afrika Çalışmaları Kongresi'nde sunulan bildiri, Ankara.

Martin, A. J. (2004). School motivation of boys and girls: Differences of degree, differences of kind, or both? Australian Journal of Psychology, 56(3), 133-146.

Merriam, S. B. (2018). Nitel araştırma desen ve uygulama için bir rehber. (S. Turan, Çev.). Ankara: Nobel Akademik Yayıncılık. (Orijinal çalışma basım tarihi Nisan 2009.)

Miles, M. B. ve Huberman, A. M. (2015). Nitel veri analizi. (S. Akbaba Altun ve A. 
Ersoy, Çev.). Ankara: Pegem Akademi Yayıncılık. (Orijinal çalışma basım tarihi Aralık 1994.)

Özdek, A. (2006). Özengen müzik eğitimi veren kurumlarda klasik gitar eğitimi. Yayımlanmamış yüksek lisans tezi, Selçuk Üniversitesi Sosyal Bilimleri Enstitüsü.

Pintrich, P. R. (2002). The role of metacognitive knowledge in learning, teaching, and assessing. Theory Into Practice, 41(4), 219-225.

Ryan, R. M. ve Deci, E. L. (2000). Intrinsic and extrinsic motivations classic definitions and new directions. Contamparary Educational Psychology, 25(1), 5467.

Say, A. (1998). Türkiye'nin müzik atlası. Ankara: Borusan Yayıncılık.

Tavşancıl, E. (2006). Tutumların ölçülmesi ve SPSS ile veri analizi. Ankara: Nobel Yayın Dağıtım.

Tepeli, H. (2018). Ankara'daki özengen müzik eğitimi veren kurumların çok yönlü incelenmesi. Yayımlanmamış yüksek lisans tezi, Necmettin Erbakan Üniversitesi Eğitim Bilimleri Enstitüsü.

Türkmen, U. (2010). Çocuğun bireysel toplumsal ve kültürel gelişiminde amatör müzik eğitiminin yeri problemleri ve çözüm önerileri. Illöğretim Online, 9(3), 960-970.

Uçan, A. (1997). Müzik eğitimi. Ankara: Müzik Ansiklopedisi Yayınları.

Uçan, A. (2005). Müzik ě̆itimi temel kavramlar-ilkeler-yaklaşımlar (3. bask1). Ankara: Evrensel Müzik Evi.

Yıldırım, A. ve Şimşek, H. (2016). Sosyal bilimlerde nitel araştırma yöntemleri (10. baskı). Ankara: Seçkin Yayıncılık.

Yıldırım-Orhan, Ş. ve Ercan, N. (2012). Yetişkin çalgı öğretmeni özellikleri. Turkish Studies, 7(4), 223-231. 